\title{
Assessment of the "Oława" Smelter (Oława, Southwest Poland) on the Environment with Ecotoxicological Tests
}

\author{
Klaudia Radlińska', Magdalena Wróbel ${ }^{1 *}$, Agnieszka Stojanowska', Justyna Rybak ${ }^{1}$ \\ 1 Wrocław University of Science and Technology, Department of Environmental Protection, Wybrzeże \\ Wyspiańskiego 27, 50-370 Wrocław, Poland \\ * Corresponding author's e-mail: magdalena.wrobel@pwr.edu.pl
}

\begin{abstract}
The aim of the research was to study the impact of "Oława" smelter on surroundings. For this purpose, water, soil and sediments were collected in the vicinity of smelter and subjected to selected ecotoxicological tests. The authors used Spirodela polyrhiza duckweed and Brachinious calyciflorus rotifer for the assessment of the water from Odra River, and Heterocypris inconqruens ostracod for the sediment studies. Triticum sativum and Avena sativa monocotyledons as well as Sinapis alba and Lepidium sativum dicotyledonous plants were used to perform the soil toxicity tests. The obtained results proved slight sediment toxicity, but no toxicity of water was observed. The inhibition of root growth of tested plants was observed suggesting the impact of toxicity on soil. The studies proved that only the area in the nearest vicinity of the "Oława" smelter is still contaminated with heavy metals and may pose a serious threat to the environment.
\end{abstract}

Keywords: Oława, smelter, toxicity

\section{INTRODUCTION}

Currently, we experience a rapid industrial development which results in an increasing amount of toxic compounds and elements released to the environment. The development of the chemical industry can have a significant impact on the environment. The substances released to the environment may affect the mortality or growth inhibition of the organisms living nearby, or may adversely affect their metabolism or physiological functions, although technological progress significantly contributes to the decrease of this impact [22]. In order to examine the state of the environment, chemical analyses are performed although ecotoxicological tests are also conducted to identify the direct impact of pollution on the living organisms.

The "Oława" smelter is located in southwestern Poland and has been operating since 1845. It produces zinc, lead and cadmium oxides [1, 20]. In the 1980s, the industry was on the list of large polluters in Poland. The annual dust emission until
1966 was 117 tons of zinc and 20.3 tons of lead. These values decreased in 2011 to $380 \mathrm{~kg}$ zinc and $0.084 \mathrm{~kg}$ lead, respectively. At present, the "Oława" smelter meets all the emission standards and has obtained the status of environmentalfriendly enterprise [7]. The previous production of zinc, lead and cadmium oxides without innovative technology resulted in the pollution of soil, water and sediments in the vicinity of smelter as it was recorded in previous papers $[8,15]$. In the studies conducted by Cuske et al. [2013] the level of zinc and lead in the soil in the vicinity of smelter was especially high, the slightly elevated level of cadmium was also recorded which was the result of the smelter activity as well as - indirectly dust movement and precipitation [1]. The high content of zinc and lead in the bottom sediments of Odra and Oława rivers was also observed [4, 5]. Zinc is an element that has a significant impact on the plant metabolism; therefore, its deficiency and excess can be harmful. The zinc deficiency can lead to disorders of protein and carbohydrate metabolism, and can impair the process of DNA 
and RNA synthesis, while the excess of this element may cause various types of plants chlorosis and necrosis [3]. Cadmium and lead can disturb the processes of photosynthesis and transformation of the nitrogen compounds [11].

The presence of trace metals causes changes in protein synthesis and disturbances in the production of ATP (adenosine-5'-triphosphate) in humans and animals. ATP is a basic multifunctional coenzyme and molecule used in the transport of chemical energy, in cell metabolism. In the case of neurons, about $70 \%$ of the ATP produced is consumed in maintaining the function of sodiumpotassium pumps [18].

As the influence of the smelter on the environment has been observed previously, the aim of the study was to assess the impact of the "Oława" smelter on soil, water and sediments using the ecotoxicological tests.

\section{MATERIALS AND METHODS}

\section{Sampling sites}

All sampling sites (1-40) were located in the vicinity of the "Olawa” smelter (ZM „Silesia" S.A.). (Fig. 1; Table 1). The bottom sediment and water samples were taken from the Odra River, in a point located $1,700 \mathrm{~m}$ from the emitter (smelter). Choosing the sampling locations, the authors took into account the wind rose for Oława; therefore, the sites were located in the west and north-west direction from the smelter. The soil control sample were taken from allotment gardens located south-east from the smelter.

The soil samples were taken at a depth of $20-30 \mathrm{~cm}$.

Site 1 is located in the vicinity of the smelter, about $200 \mathrm{~m}$ from the main pollution emitter (chimney). The soil was classified as low-loamy sand, belonging to light soils. The area is characterized by relatively low biodiversity of vegetation. The following plant species were distinguished: plantain, sorrel, celandine, wart birch, pine. The area is also covered with mosses. The surroundings include the old arm of Odra river, remains of the railway line to the river port and sidings from the smelter. From the $90 \mathrm{~s}$, the route track was almost unused, and after 2000, it was demolished.

Site 2 is located about $450 \mathrm{~m}$ from the steel mill, in the garden next to a residential building.

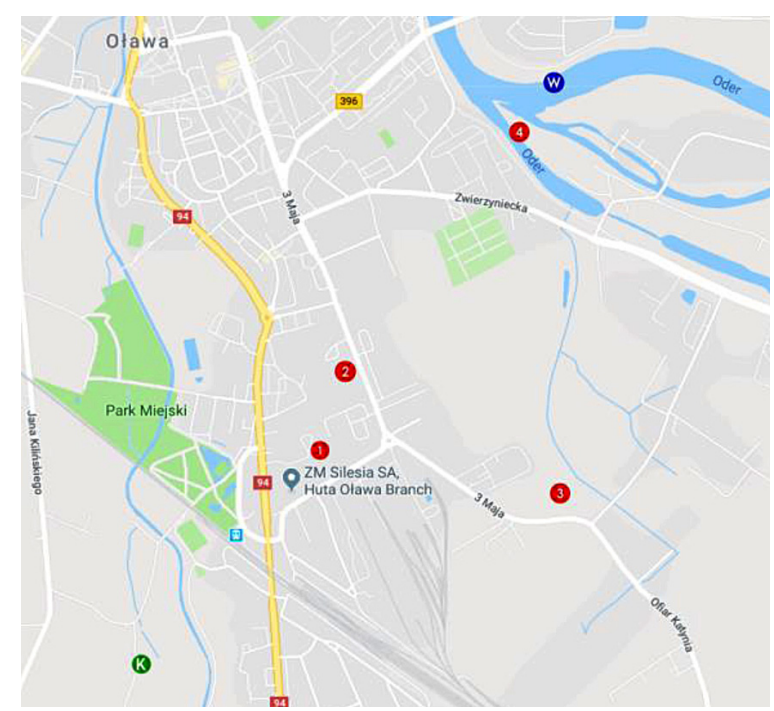

Fig. 1. Location of soil, water and sediment sampling sites (map source: https://www.google.com/maps)

In the vicinity, there is a Tesco supermarket, built on the grounds of a former sawmill, demolished before 2005. Due to the presence of the sawmill, the possibility of increased soil fertility should be taken into account. The soil was classified as slack-bogged sand. The area is characterized by low vegetation diversity, blackberry, nettle, panicle and mosses were recorded.

Site 3 is located $900 \mathrm{~m}$ from the pollution emitter, in the green area characterized by a large diversity of flora; the following plant species have been recorded: oak, wart birch, purple jasmine, sorrel, common borscht, common curd, cuddly tansy, common tansy, cellulose moss, sphagnum moss, and many grass species. The soil belongs to light loamy sands.

Site $\mathbf{4}$ is located on the so-called island, about $1500 \mathrm{~m}$ from the smelter. Soils are loamy sand. High biodiversity of vegetation was found, including the presence of following species: double-necked hawthorn, maple, pedunculate oak, tansy, mugwort, common yarrow, common

Table. 1. Soil sampling sites and their distance from the "Oława" smelter

\begin{tabular}{|c|c|}
\hline Sample no. & Distance from the smelter \\
\hline Control & $750 \mathrm{~m}$ \\
\hline 1 & $200 \mathrm{~m}$ \\
\hline 2 & $450 \mathrm{~m}$ \\
\hline 3 & $700 \mathrm{~m}$ \\
\hline 4 & $1400 \mathrm{~m}$ \\
\hline
\end{tabular}


ryegrass, arboreal, forest chervil, cuddly, as well as a large variety of other panicles.

\section{METHODS}

\section{Spirodela Duckweed Toxkit}

Spirodela Duckweed Toxkit is a 72-hour biotest for assessing the toxicity of water and wastewater, which consists of assessing the growth inhibition of first fronds of Spirodela polyrhiza in a prepared series of dilutions after 3 days of incubation. Growth is determined on the basis of the pictures taken before and after 72 hours of incubation [21].

\section{Rototoxkit F}

Rotoxkit $\mathrm{F}$ is an acute toxicity biotest which uses Brachinious calyciflorus rotifers and rely on assessing their growth inhibition and mortality after 48 hours of incubation in water [16].

\section{Ostracodtoxkit $F$}

Chronic sediment toxicity test was conducted using Heterocypris inconqruens crustacean species. It is based on exposing the specimens to the contaminated sediment over 6 days and then determining the mortality and growth inhibition. The growth inhibition is determined by comparing the length of the specimens exposed to contaminated sludge for 6 days with the ones exposed to the reference (non-toxic) sediments [12].

\section{Phytotoxkit F}

This is three day acute toxicity test, which is based on a quantitative assessment of seed germination and growth inhibition of plants: monocots (Triticum sativum, Avena sativa) and dicotyledons (Lepidum sativum and Sinapis alba) by determining the number of germinated seeds and their shoot and root length. These parameters are compared with the shoot and root length of the plants grown on the control soil (uncontaminated soil, rich in organic substances) [13].

\section{RESULTS AND DISCUSSION}

\section{Spirodela Duckweed Toxkit}

Table 2 shows the comparison of the average area values for the first frond of S. polyrhi$z a$ and the percentage increase of this area in relation to the control for the water taken from the Odra River.

The area growth after 3 days of incubation ranged from $238 \%$ for the non-diluted sample of water $(100 \%)$ to $521 \%$ (dilution $25 \%$ ). The growth percentage increase of the first frond area in the control sample was $330 \%$. A significant and constant increase in the frond area at the dilution range $6.25-25 \%$ of water samples was observed, then the area decreased. This can be caused probably by the impact of pollutants (metals from the smelter present in the water samples). A mixture of $75 \%$ medium and $25 \%$ water probably had the highest ratio of nutrients to toxic compounds and then exibited the largest increase in the frond surface. For pure tested water (100\%) a $27 \%$ inhibition of the frond growth compared to the control was recorded, which suggests a toxic effect of the "Oława" smelter on the water quality in the Odra River.

\section{Rototoxkit F}

The studies on the water toxicity with rotifers were conducted on the Odra River water samples too. The recorded rotifers mortality is given in Table 3.

One specimen was found dead in 50\% dilution of the wateronly. For the rest of the studied samples,

Table 2. The comparison of the average area $\left[\mathrm{mm}^{2}\right.$ and $\left.\%\right]$ of the first frond for time $0 \mathrm{~h}$ (the beginning of the experiment) and after $72 \mathrm{~h}$ of incubation for water samples from Odra River

\begin{tabular}{|c|c|c|c|c|c|}
\hline Dilution & $\begin{array}{c}\text { Average area of frond } \\
\text { after } 0 \mathrm{~h}\left[\mathrm{~mm}^{2}\right]\end{array}$ & $\begin{array}{c}\text { Average area of frond } \\
\text { after } 72 \mathrm{~h}\left[\mathrm{~mm}^{2}\right]\end{array}$ & $\begin{array}{c}\text { Increase of the } \\
\text { area [mm²] }\end{array}$ & $\begin{array}{c}\text { Percentage increase } \\
\text { of the area [\%] }\end{array}$ & $\begin{array}{c}\text { Percentage increase in } \\
\text { relation to control [\%] }\end{array}$ \\
\hline Control & 1.27 & 6.73 & 5.45 & 329.13 & - \\
\hline 6.25 & 1.22 & 6.99 & 5.78 & 373.77 & 13.56 \\
\hline 12.5 & 1.71 & 10.77 & 9.06 & 429.82 & 30.59 \\
\hline 25 & 1.29 & 9.3 & 8.02 & 521.71 & 58.51 \\
\hline 50 & 1.34 & 8.87 & 7.53 & 461.94 & 40.35 \\
\hline 100 & 1.53 & 7.4 & 5.86 & 238.01 & -27.7 \\
\hline
\end{tabular}


Table 3. Results of Rotoxkit $F$ for the Odra River water samples for time $0 \mathrm{~h}$ (the beginning of the experiment) and after $72 \mathrm{~h}$

\begin{tabular}{|c|c|c|c|}
\hline Concentration & $\begin{array}{c}\text { Number } \\
\text { of living } \\
\text { organisms } \\
\text { in 0 } \mathrm{h}\end{array}$ & $\begin{array}{c}\text { Number } \\
\text { of living } \\
\text { organisms } \\
\text { after 48 } \mathrm{h}\end{array}$ & $\begin{array}{c}\text { Average } \\
\text { percentage } \\
\text { of mortality } \\
(\%)\end{array}$ \\
\hline Control & 8 & 8 & 0 \\
\hline 6,25 & 8 & 8 & 0 \\
\hline 12,5 & 8 & 8 & 0 \\
\hline 25 & 8 & 8 & 0 \\
\hline 50 & 8 & 7 & 12.5 \\
\hline 100 & 8 & 8 & 0 \\
\hline
\end{tabular}

no mortality was observed. The water from the Odra River is considered as non-toxic to animals.

\section{Ostracodtoxkit F}

In order to assess the toxicity of the sediments from the Odra River, the length of crustaceans on the first and sixth days of the experiment was measured and the mortality percentage and growth inhibition percentage were recorded. The results are shown in Table 4.

The test showed that the sediments collected in the vicinity of the "Oława" smelter are toxic, as the length of tested organisms after 6 days of incubation was low $(400 \mathrm{~mm})$ comparing to control $(837 \mathrm{~mm})$ and mortality $(63.3 \%)$ of ostracods was observed in relation to the control. Probably, the proper development of crustaceans was inhibited by the toxicants accumulated in sediments.

\section{Phytotoxkit F}

The growth inhibition percentage of shoot and root length of higher plants at studied sites is presented in relation to the control in Tables 5-8.

Only slight inhibition of root and shoot growth was observed at site 1, and a slight inhibition of root growth at site 2 in relation to control soil for monocot plants T. aestivum and A. sativa, the stimulation of growth was recorded in other sites for shoots and roots of both plant species.
The soil from all sites influenced the root growth of both dicotyledons plants - L. sativum and $S$. alba. The highest inhibition was observed in the nearest site of smelter (site 1). The highest root growth inhibition was observed at the closest distance from the smelter to the studied site. The shoots of both plants were less sensitive to the toxic compounds in the soil. Their growth inhibition occurred only at site 1 , the soil from other sites (2-4) did not inhibit the shoot growth.

Our studies proved that the "Olawa" smelter still has an impact on the surrounding environment, although industry has improved significantly and now applies the modern, eco-friendly technologies in processing toxic metals. Nevertheless, no toxicity was found in the Odra River water, based on the studies. This result is consistent with other studies [5]. In our tests, S. polyrhiza and $B$. calyciflorus, the species with a significant sensitivity to the toxic effect of cadmium and lead, have been used. However, according to Gaur et al. [2] and Santos-Medrano \& Rico-Martinez [17] both species B. calyciflorus and $S$. polyrhiza have a high tolerance to the harmful effect of zinc. Thus, the lack of toxic effects, i.e. no mortality of rotifers and the lack of significant inhibition of the $S$. polyrhiza growth, clearly indicates the lack of elevated levels of heavy metals in the Odra River. A slight growth inhibition of the frond surface of $S$. polyrhiza was found only in the non-diluted water $(100 \%)$; thus, this water probably does not have a sufficient content of biogenic elements necessary for the proper growth of these plants.

$H$. incongruens was used to assess the toxicity of sediments from the Odra River. Other researchers $[9,10]$ have proved the sensitivity of ostracods to highest concentrations of cadmium, zinc and lead. According to Kudłak et al. [15] and Sevilla et al. [19] cadmium is one of the most harmful elements for $H$. incongruens. The cadmium content nearest the study area was $0.26 \mathrm{ppm}$ and $1.06 \mathrm{ppm}$, respectively [6]. In our research, the mortality rate of crustaceans was $64 \%$; thus, the harmful effect of sediment on $H$. incongruens was not very strong. Currently, toxins practically did not infiltrate into the water owing to the

Table 4. The results of Ostracodtoxkit $\mathrm{F}$ for the samples of sediments from the Odra River

\begin{tabular}{|c|c|c|c|c|}
\hline Site & $\begin{array}{c}\text { The average length of the } \\
\text { body day } 0[\mathrm{~mm}]\end{array}$ & $\begin{array}{c}\text { The average length of the } \\
\text { body day } 6[\mathrm{~mm}]\end{array}$ & Mortality [\%] & Growth inhibition [\%] \\
\hline Control & 150 & 837 & - & - \\
\hline Odra river & 150 & 400 & 63.33 & 63.59 \\
\hline
\end{tabular}


Table 5. Percentage [\%] of growth inhibition of root T. sativum and A. sativa in the studied sites (soil). "+" means no inhibition but increase

\begin{tabular}{|c|c|c|}
\hline Soil sample No. & T. aestivum & A. sativa \\
\hline Site 1 & +3.7 & 2.7 \\
\hline Site 2 & +5.5 & 13.2 \\
\hline Site 3 & +46.8 & +49.8 \\
\hline Site 4 & +56 & +37.9 \\
\hline
\end{tabular}

Table 7. Percentage [\%] of growth inhibition of root L. sativum and S. alba in the studied sites (soil)

\begin{tabular}{|c|c|c|}
\hline Soil sample No & L. sativum & S. alba \\
\hline Site 1 & 63.1 & 71.5 \\
\hline Site 2 & 43.1 & 41.2 \\
\hline Site 3 & 16.3 & 3.1 \\
\hline Site 4 & 11.6 & 3.3 \\
\hline
\end{tabular}

advanced technology employed in the smelter; thus, it is possible that the water underwent a selfpurification process, and only small amounts of toxic compounds are still deposited in sediments.

The studies on the soil toxicity showed that mocotyledons, $T$. sativum and A. sativa, exhibit a higher tolerance to the toxic compounds present in soil, in contrast to dicotyledons plants $L$. sativum and $S$. alba, which had significantly higher sensitivity to them. Szałata \& Doskocz [14] proved that the monocotyledonous plants showed low ability to accumulate metals, including cadmium, lead and zinc in comparison to dicotyledonous plants which are very good bioaccumulators. This was confirmed by our results, as the inhibition of root growth was observed mainly in dicotyledons plants L. sativum and S. alba. A general decrease in the root growth relative to the shoot growth was also observed, which can be explained by a direct contact of the roots with the toxins. Site 1, located in the nearest vicinity of smelter, showed the greatest effect of inhibition of dicotyledonous plant growth, smaller toxic effects and a simultaneous decrease in the content of soil pollutants were observed with an increasing distance from the emitter (sites 2, 3 and 4).

\section{CONCLUSIONS}

1. No significant toxic effects of the Odra water on plants and animals were found, based on the Rototoxkit F and Spirodela Duckweed Toxkit
Table 6. Percentage [\%] of growth inhibition of shoot T. aestivum and A. sativa in the studied sites (soil). "+" means no inhibition but increase

\begin{tabular}{|c|c|c|}
\hline Soil sample No. & T. aestivum & A. sativa \\
\hline Site 1 & +32 & 17.5 \\
\hline Site 2 & +49.4 & +18.8 \\
\hline Site 3 & +73 & +27 \\
\hline Site 4 & +89.3 & +39.5 \\
\hline
\end{tabular}

Table 8. Percentage [\%] of growth inhibition of shoot L. sativum and S. alba in the studied sites (soil).

"+" means no inhibition but increase

\begin{tabular}{|c|c|c|}
\hline Soil sample no & L. sativum & S. alba \\
\hline Site 1 & 26.7 & 37.6 \\
\hline Site 2 & +24 & +38.2 \\
\hline Site 3 & +30.8 & +63.5 \\
\hline Site 4 & +63.1 & +78.8 \\
\hline
\end{tabular}

tests, which suggests that the modern technologies employed in smelter are efficient in the reduction of pollution produced previously by this industry.

2. A slight toxicity was observed in the sediment taken at the same point as water (Odra River) to study. The authors observed $64 \%$ of mortality rate for ostracods (Ostracodtoxkit F). The old contaminants coming from the past activity of smelter, when the technologies related to the processing of metals did not protect the environment, are probably still deposited in the sediments.

3. Soil contamination in the nearest neighborhood of "Olawa" smelter was recorded with the use of Phytotoxkit F. However, the areas located east and west of the smelter at a distance of minimum $900 \mathrm{~m}$ are already free from contamination.

4. Due to the proximity of residential buildings and home gardens in the surroundings of the "Oława" smelter, it is not recommended to grow edible plants or breed animals due to the risk of heavy metal poisoning.

\section{Acknowledgements}

The investigations were co-financed within the framework of order No. 049U/0034/19 with a specific subsidy granted to the Faculty of Environmental Engineering, Wroclaw University of Science and Technology (W-7), by the Minister of Science and Higher Education. 


\section{REFERENCES}

1. Cuske M., Marcinkiewicz M., Szopka K., Karczewska A., Pora E., 2013. Oddziaływanie Huty Cynku Oława na środowisko glebowe terenów przyległych, w świetle całkowitej za-wartości metali ciężkich w poziomach powierzchniowych gleb miasta Oławy, Zeszyty Naukowe. Inżynieria Środowiska / Uniwersytet Zielonogórski, 149 (29), 42-50

2. Gaur J.P., Noraho N., Chauhan Y.S. 1994. Relationship between heavy metal accumulation and toxicity in Spirodela polyrhiza (L.) Schleid. and Azolla pinnata R. Br. Aquatic Bo-tany, 49 , 2-3, 183-192

3. Gruca-Królikowska S., Wacławek W. 2006. Metale w środowisku cz. II, Wpływ metali ciężkich na rośliny, Chemia Dydaktyka Ekologia Metrologia, $1-2,41-55$.

4. http://www.gios.gov.pl/pl/stan-srodowiska/monitoring-wod, Ocena stanu jednolitych części wód rzek i zbiorników zaporowych w roku 2017

5. http://www.gios.gov.pl/pl/stan-srodowiska/monitoring-wod, Ocena stanu jednolitych części wód rzek i zbiorników zaporowych w latach 2011 - 2016.

6. http://www.gios.gov.pl/pl/stan-srodowiska/monitoring-wod, Wyniki badań i ocena kompleksowa stanu osadów dennych rzek i jezior w latach 2016-2017.

7. http://www.hutaolawa.pl/pl/index.html

8. https://www.wroclaw.pios.gov.pl/pliki/ raporty/2001/5_Gleby.pdf,

9. Kudłak B, Wolska L., Namieśnik J. 2011. Determination of EC50 toxicity data of selected heavy metals toward Heterocypris incongruens and their comparison to ,direct-contact” and microbiotst. Environ Monit Assess, 174, 509-516

10. Kyoshiro H., Tobino T., Nakajima F., TsukuharaK. 2017 .Duration of life-cycle toxicity tests with the ostracod Heterocypris incongruens, Environmental Toxicology and Chemistry, 36, 3443-3449

11. Ociepa-Kubicka A., Ociepa E. 2012. Toksyczne oddziaływanie metali ciężkich na rośliny, zwierzęta i ludzi, Inżynieria i Ochrona środowiska. 15, $169-180$

12. Ostracodtoxkit F Chronic "direct contact" toxicity test for freshwater sediments. Standard Operational Procedure (2017)

13. Phytotoxkit $F$ test in assessment of toxicity of two types of sewage sludge standard operational procedure (2017)

14. Pytlik E., Kalinichenko A. 2017. Rośliny naczyniowe jako bioindykatory stanu środowiska, [in:] Szałata Ł., Doskocz J. (red.), Innowacje w naukach ścisłych, Wydawnictwo Nauka i Biznes, Brzeziny

15. Raport początkowy dla Oddział Huty Oława w Oławie, ZM Silesia S.A., na podstawie zamówienia nr HO-Ś -2015-19, http://bip.wroclaw. rdos.gov.pl/files/obwieszczenia/109997/raportpocz $\%$ C4\%85tkowy-Huta-O\%C5\%82awa.pdf

16. Rototoxkit F Chronic test in assesment of toxicity of freshwater. Standard Operational Procedure (2017)

17. Santos-Medrano G. E and R. Rico-Martínez. 2013. Lethal effects of five metals on the freshwater rotifers Asplanchna brigthwellii and Brachionus calyciflorus. Hidrobiológica 23 (1),82-86.

18. Seńczuk W.: Toksykologia współczesna. Wydawnictwo Lekarskie PZWL, Warszawa 2005.

19. Sevilla J.B., Nakajima F., Kasuga I. 2014. Comparison of aquatic and dietary exposure og heavy metals $\mathrm{Cd}, \mathrm{Cu}$ and $\mathrm{Zn}$ to benethic ostracod Heterocypris incongruens, Environmental Toxicology and Chemistry. 33, 1624-1630

20. Sobczak. A. 2012. Health hazardous ChemiCal Compounds in the human environment, Environmental Medicine, 15 (1)

21. Spirodela Duckweed Toxkit test in assesment of toxicity of freshwater. Standard Operational Procedure (2017)

22. Traczewska T. 2011. Biologiczne metody oceny skażenia środowiska, Oficyna Wydawnicza Politechniki Wrocławskiej, Wrocław 